https://journal.unnes.ac.id/sju/index.php/baej

\title{
PERSEPSI MAHASISWA TENTANG IMPLEMENTASI BLENDED LEARNING PADA MATA KULIAH STRATEGI PEMBELAJARAN AKUNTANSI
}

\section{Yolandaru Septiana}

Jurusan Pendidikan Akuntansi, Fakultas Ekonomi, Universitas Negeri Yogyakarta, Indonesia

\section{Info Artikel}

Sejarah Artikel:

Diterima: 4 Agustus 2020

Disetujui: 1 Oktober 2020

Dipublikasikan: 31

Desember 2020

\section{Keywords:}

Implementasi, Blended

Learning; Strategi

pembelajaran Akuntansi

\begin{abstract}
Abstrak
Penelitian ini bertujuan untuk mendeskripsikan persepsi mahasiswa tentang implementasi blended learning dalam mata kuliah Strategi Pembelajaran Akuntansi. Penelitian ini adalah penelitian kuantitatif survei. Sampel penelitian ini adalah mahasiswa Prodi Pendidikan Akuntansi, Fakultas Ekonomi, Universitas Negeri Yogyakarta yang telah mengambil mata kuliah Strategi Pembelajaran Akuntansi, sebanyak 36 mahasiswa. Teknik pengumpulan data menggunakan kuesioner. Data dianalisis menggunakan deskriptif kuantitatif. Hasil penelitian yaitu (1) persepsi mahasiswa tentang blended learning sebagai sistem baru, mudah, dan efektif, (2) Blended learningBesmart membuat sebagian besar mahasiswa merasa bertanggung jawab, termotivasi dan terbantu membuat perencanaan, dan melakukan persiapan sebelum di kelas, (3) Mahasiswa dapat belajar di lingkungan yang nyaman, sesuai dengan kecepatan mereka sendiri dan dapat belajar berulang kali, (4) Terdapat 38,89\% mahasiswa berpendapat bahwa Besmart lebih baik daripada metode lain (5) Sebagain kecil mahasiswa berpendapat bahwa mereka merasa bosan dan sulit untuk belajar melalui Besmart.
\end{abstract}

\section{Abstract}

This study aims to describe students' perceptions about the implementation of blended learning in the Accounting Learning Strategies subject. This research is a quantitative survey research. The sample of this research is 36 students of the Department of Accounting Education students, Faculty Economics, Universitas Negeri Yogyakarta who have taken the Accounting Learning Strategy subject. The data collection technique used a questionnaire. Data were analyzed using quantitative descriptive. The results of the study were (1) students' perceptions of blended learning as a new, easy, and effective system, (2) Be-smart blended learning made most students feel responsible, motivated and helped to make plans, and make preparations before class, (3) Students can study in a comfortable environment, at their own pace and can learn repeatedly, (4) There are $38.89 \%$ of students think that Be-smart is better than other methods (5) A small proportion of students think that they feel bored and find it difficult to learn through Be-smart.

Alamat korespondensi:

Gedung L2 Lantai 1 FEUnnes

Kampus Sekaran, Gunungpati, Semarang, 50229

E-mail: afifah_alkhanza@yahoo.com 


\section{PENDAHULUAN}

Revolusi industri 4.0 biasa disebut era digital. Revolusi industri terkait erat dengan Internet of Things (IoT), Cyber Physical System (CPS), Information and Communications Technology (ICT), Enterprise Architecture (EA), dan Enterprise Integration (EI) (Lu, 2017). Oleh karena itu, revolusi industri menuntut agar tren tersebut segera terwujud dengan munculnya robot baru dan inovasi produk otomasi (Aiman et al., 2016).

Saat ini, era digital sebagai wujud revolusi industry 4.0 juga merambah di dunia pendidikan.Era digital dalam pendidikan mengharuskan pembelajaran yang berpusat pada peserta didik, komunikasi interaktif, kemandirian, dan pendidik sebagai fasilitator.Oleh karena itu, era digitalisasi pendidikan menuntut adanya inovasi. Salah satu inovasi dalam pembelajaran adalah menggunakan blended learning.

Blended learning adalah kombinasi instruksi dari pembelajaran online dan pembelajaran tatap muka untuk membantu mengembangkan pengetahuan dan keterampilan baru (Porter et al., 2014;Hilliard, 2015). Blended learning terjadi ketika ada kesempatan peserta didik berdiskusi dalam forum asinkron kemudian pendidik menjelaskan secara langsung/sinkron atau konferensi video, dan ketika kuliah atau kegiatan pelatihan diadakan secara virtual daripada tatap muka (Bonk \& Kim, 2004). Oleh karena itu menurut Stockwell et al., (2015)blended learning merupakan paradigma yang muncul dalam pendidikan sains tetapi tidak menggunakan penilaian yang kaku.Menurut Porter etal. (2014)bahwa tujuan utama universitas menerapkan blended learning adalah untuk mengembangkan pedagogi.Sedangkan manfaat dari blended learning adalah temporal dan atau mempertimbangkan akses geografis dan fleksibilitas, maka universitas juga menyebutkan bahwa blended learning memiliki biaya yang efektif (Porter et al., 2014). Dalam blended learning, potensi peserta didik sangat dibutuhkan terutama kemandirian belajar mereka. Kegunaan lain dari blended learning adalah untuk meningkatkan kemampuan peserta didik dalam membangun pengetahuan, serta kemampuan untuk menilai dan mengevaluasi sehingga akan menghasilkan peserta didik yang terampil yang dapat menjadi lulusan inovatif yang mampu memenuhi kebutuhan kerja melalui kreativitas dan inovasi mereka (Kintu et al., 2017).

Universitas Negeri Yogyakarta memiliki program e-learning yang disebut Besmart. Besmart ini sebagai salah satu sarana untuk melakukan blended learning. Salah satu mata kuliah yang menggunakan blended learning adalah Strategi Pembelajaran Akuntansi pada Program Studi Pendidikan Akuntansi, Fakultas Ekonomi, Universitas Negeri Yogyakarta. Mata kuliah Strategi Pembelajaran Akuntansi adalah mata kuliah yang membahas berbagai strategi pembelajaran yang dapat digunakan dalam bidang pengajaran akuntansi. Penggunaan blended learning dalam kuliah ini adalah kombinasi dari pembelajaran online menggunakan Besmart dan pembelajaran tatap muka di kelas. Pembelajaran onlinedenganBesmart berisi materi pembelajaran dalam bentuk modul dan slide PowerPoint, artikel dari jurnal, video pembelajaran, forum diskusi, kuis, tugas, dan latihan. Dengan demikian, mahasiswa dapat belajar secara mandiri secara online. Pembelajaran tatap muka berisi penyampaian materi, latihan, dan praktik melakukan simulasi pembelajaran akuntansi menggunakan berbagai strategi pembelajaran. Implementasi blended learning untuk kuliah ini adalah 1 semester. Desain instruksional dalam blended learning dimulai dengan mendesain ulang rencana pelajaran dan menulis ringkasan kuliah. Materi pembelajaran yang disiapkan yaitu untuk kegiatan tatap muka dengan $e$ learning. Sumber dan bahan pembelajaran dikembangkan sesuai dengan tujuan pembelajaran maka kegiatan review yang berkelanjutan sangat dibutuhkan (Cheung et al., 2010).

Pentingnya dilakukan penelitian ini adalah untuk mengeksplorasi persepsi mahasiswa tentang Blended Learning dalam mata kuliah Strategi Pembelajaran Akuntansi, kemudian hasil penelitian ini untuk memberikan masukan atau saran implementasi 
blended learning ke depannya. Tujuan penelitian ini adalah untuk menggambarkan persepsi mahasiswa tentang implementasi blended learning dalam mata kuliah Strategi Pembelajaran Akuntansi.

\section{METODE}

Penelitian ini termasuk penelitian kuantitatif jenis survey.Sampel penelitian ini adalah mahasiswa Prodi Pendidikan Akuntansi, Fakultas Ekonomi, Universitas Negeri Yogyakarta yang telah mengambil mata kuliah Strategi Pembelajaran Akuntansi, sebanyak 36 mahasiswa. Teknik pengumpulan data menggunakan kuesioner. Kuesioner penelitian ini mengadaptasi kuesioner dari penelitian yang dilakukan oleh Akkoyunlu \& Yilmaz-Soylu (2008). Teknik analisis data dalam penelitian ini dilakukan dengan mereduksi data, menyajikan data dan menarik kesimpulan.

\section{HASIL DAN PEMBAHASAN}

Objek penelitian ini adalah persepsi mahasiswa Prodi Pendidikan Akuntansi UNY tentang implementasi blended learning pada mata kuliah Strategi Pembelajaran Akuntansi. Persepsi ini penting dilakukan untuk memberikan masukan atau saran implementasi blended learning di masa depan.

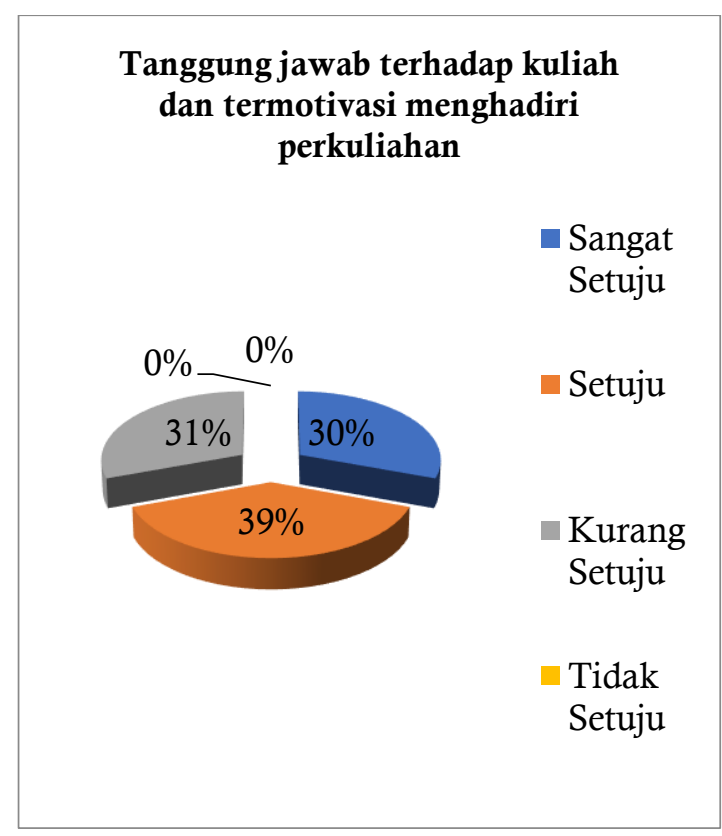

Gambar 1.Tanggung jawab terhadap kuliah dan termotivasi menghadiri perkuliahan.

Berdasarkan gambar 1 di atas, 69.44\% mahasiswa berpikir bahwa mereka merasa bertanggung jawab untuk kuliah dan termotivasi.Blended learning memberi mahasiswa rasa tanggung jawab untuk studi mereka dan memotivasi mereka untuk antusias menghadiri kuliah.Hal itu disebabkan berbagai faktor, salah satunya adalah kombinasi pembelajaran tatap muka dengan pembelajaran online, sehingga mahasiswa dapat belajar bertanggung jawab untuk memahami materi pembelajaran, mengerjakan kuis, memberikan ide dalam forum diskusi di Besmart. Hasil ini relevan dengan penelitian yang dilakukan oleh Al-ani (2013)bahwa penggunaan pendekatan blended learning dapat mempengaruhi motivasi siswa dan prestasi belajar, kolaborasi dan komunikasi yang dirasakan oleh peserta didik, dan menganalisis hambatan peserta didik ketika menggunakan Moodle dalam blended learning.

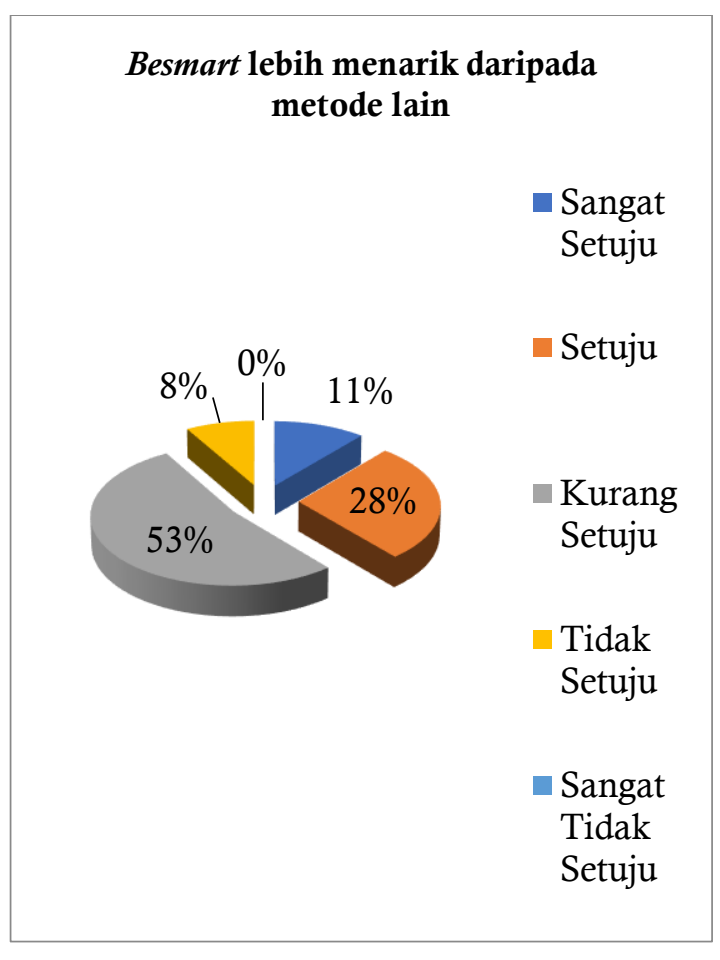

Gambar 2.Besmart lebih menarik daripada metode lain.

Gambar 2 memberikan informasi bahwa $38.89 \%$ mahasiswa berpikir situs Besmart lebih menarik daripada metode lain. Hal ini menunjukkan bahwa mayoritas mahasiswa menganggap Besmart kurang menarik daripada 
metode lain. Hal itu karena konten yang disajikan di Besmart kurang menarik, kuis yang disajikan belum memberikan tantangan bagi mahasiswa, dan forum diskusi yang berjalan tidak optimal. Sementara itu, ada perbedaan dalam persepsi konteks pembelajaran terkait dengan motivasi belajar dan strategi pembelajaran, dan ada perbedaan dalam bentuk memori yang terkait dengan strategi pembelajaran dan bagaimana menyelesaikan tugas-tugas akuntansi yang terkait dengan persepsi peserta didik tentang persyaratan kuliah (Jackling, 2005).

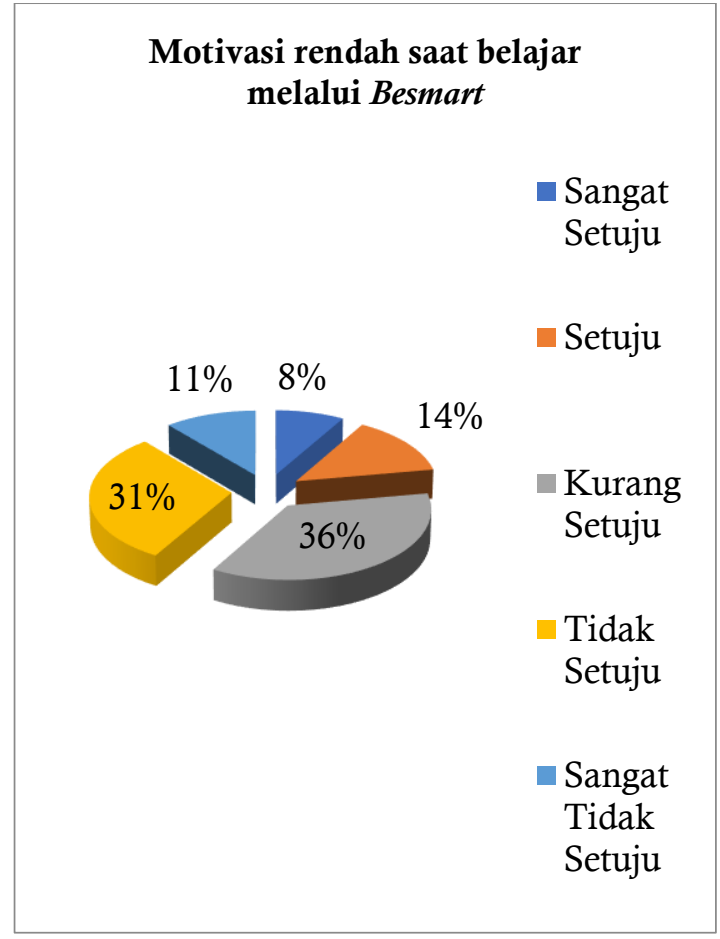

Gambar 3. Motivasi rendah saat belajar melalui Besmart.

Berdasarkan gambar 3, dapat dilihat bahwa $77,78 \%$ mahasiswa tidak setuju bahwa motivasi belajar melalui Besmart rendah. Mayoritas mahasiswa berpikir bahwa belajar melalui Besmart memberi mereka motivasi tinggi. Hal itu karena belajar melalui Besmart bisa dimana saja dan kapan saja, antar mahasiswa dapat aktif berdiskusi, bisa langsung mengetahui skor setelah mengerjakan kuis. Ada 4 faktor yang dapat mempengaruhi motivasi siswa, yaitu: kompetensi mengajar, karakteristik individu, keahlian materi pelajaran, dan hubungan guru-siswa (Xiao, 2012).

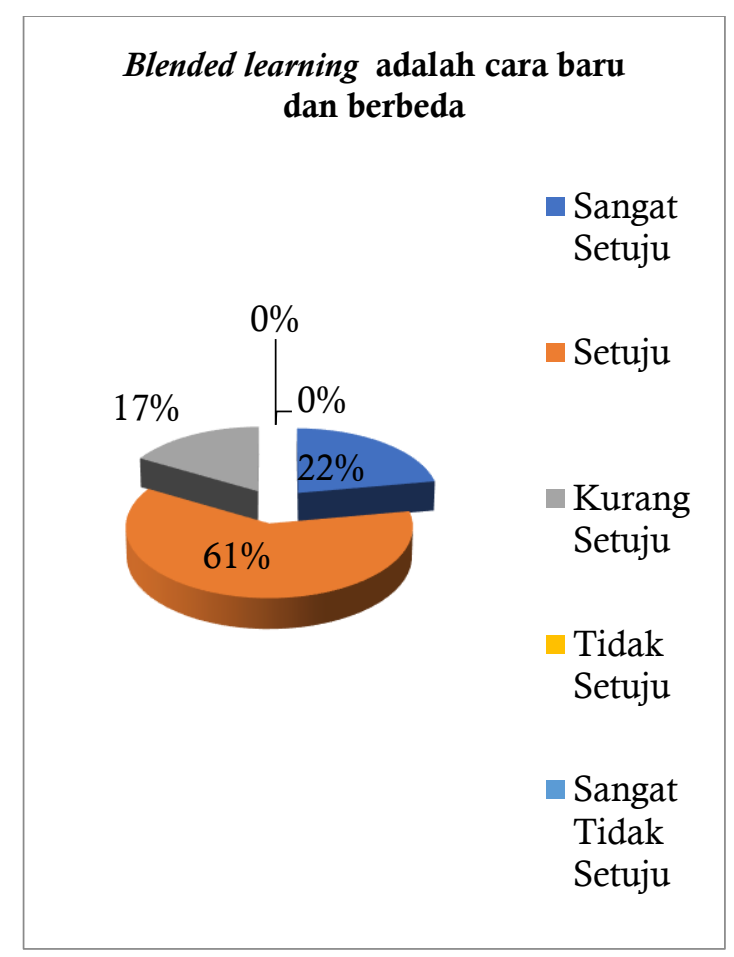

Gambar 4.Blended learningadalah cara baru dan berbeda

Berdasar gambar 4 memberikan ilustrasi bahwa $83.33 \%$ mahasiswa berpikir bahwa blended learning adalah cara yang baru dan berbeda. Mahasiswa memiliki gagasan bahwa blended learning adalah cara baru dibandingkan dengan model pembelajaran lainnya. Blended learning menempatkan lebih banyak penekanan pada berpusat pada mahasiswa, sehingga mahasiswa secara aktif terlibat dalam pembelajaran. Model pembelajaran tradisional masih berpusat pada pendidik sehingga para pendidik secara aktif menjelaskan (memberi ceramah).

\section{Mahasiswa merasa sulit belajar} melalui Besmart

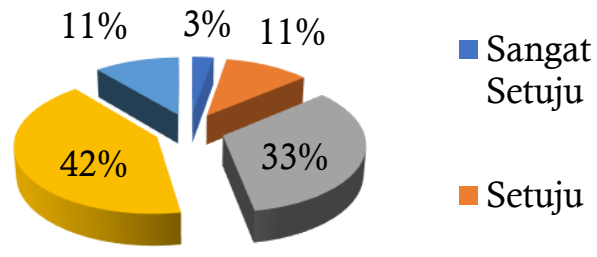


Gambar 5. Mahasiswa merasa sulit belajar melalui Besmart

Gambar 5 menjelaskan bahwa 13.89\% mahasiswa merasa sulit untuk belajar melalui Besmart. Berdasarkan diagram tersebut dapat dilihat bahwa mayoritas mahasiswa tidak merasa kesulitan mengakses Besmart. Mahasiswa yang merasa sulit untuk belajar melalui Besmart itu dikarenakan faktor teknis, misalnya: jaringan internet yang tidak stabil, dan banyak langkah yang perlu diambil ketika mengakses Besmart. Sementara itu, penelitian yang dilakukan oleh Owston et al.,(2013)menjelaskan tentang perbandingan peserta didik berkemampuan tinggi dengan peserta didik berkemampuan rendah, peserta didik berkemampuan tinggi merasa lebih puas dengan blended learning, dan lebih memilih blended learning daripada lebih tatap muka atau online. Mahasiswa berkemampuan tinggi juga merasa lebih nyaman, lebih menarik, dan mereka belajar konsep-konsep inti dari pembelajaran dengan blended learning daripada pembelajaran tatap muka. Implikasi dari hasil penelitian ini adalah bahwa peserta didik berkemampuan rendah tidak dapat menguasai lingkungan belajar campuran. Dengan demikian, universitas mungkin dapat menawarkan peserta didik pilihan antara mendaftar di bagian kuliah campuran atau tatap muka sepenuhnya, terutama pada materi yang sulit bagi peserta didik.

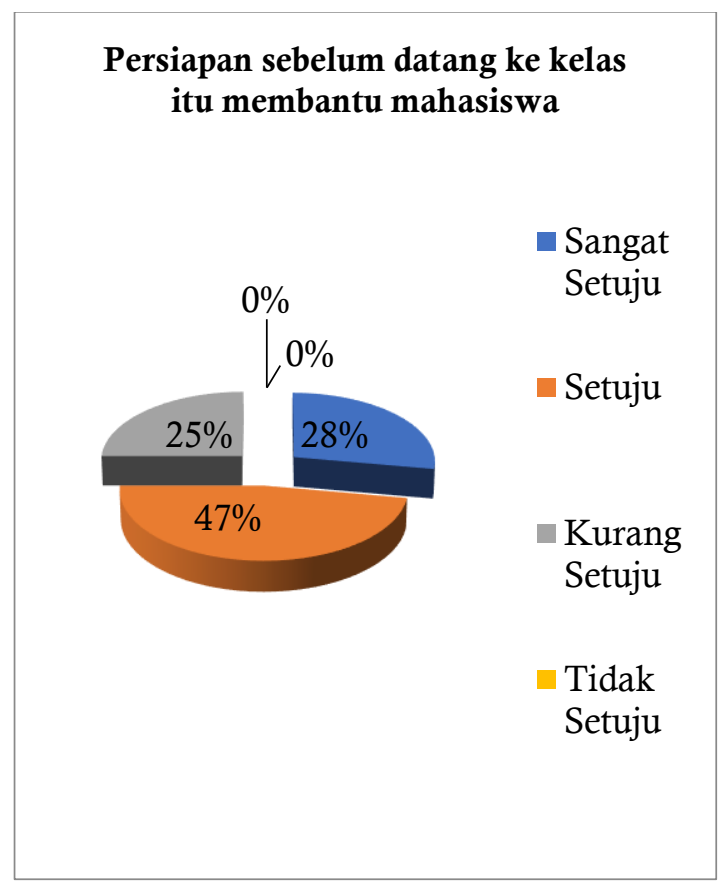

Gambar 6.Persiapan sebelum datang ke kelas itu membantu mahasiswa

Berdasar gambar 6, sebanyak $75 \%$ mahasiswa berpikir bahwa persiapan sebelum masuk kelas itu sangat membantu. Persiapan untuk belajar sebelum memasuki kelas adalah penting, karena mahasiswa sudah belajar tentang materi yang akan dibahas di kelas dan kemudian di kelas akan berdiskusi dengan dosen. Hal ini berarti bahwa mahasiswa sudah memiliki deskripsi awal dari materi kuliah dan akan memfasilitasi proses pembelajaran. Ketika mahasiswa membuat persiapan sebelum pergi ke kelas, itu akan mengurangi masalah belajar. Stockwell et al. (2015)menjelaskan bahwa menyelesaikan masalah di kelas dapat meningkatkan kinerja ujian, dan tugas video dapat meningkatkan kehadiran dan kepuasan.

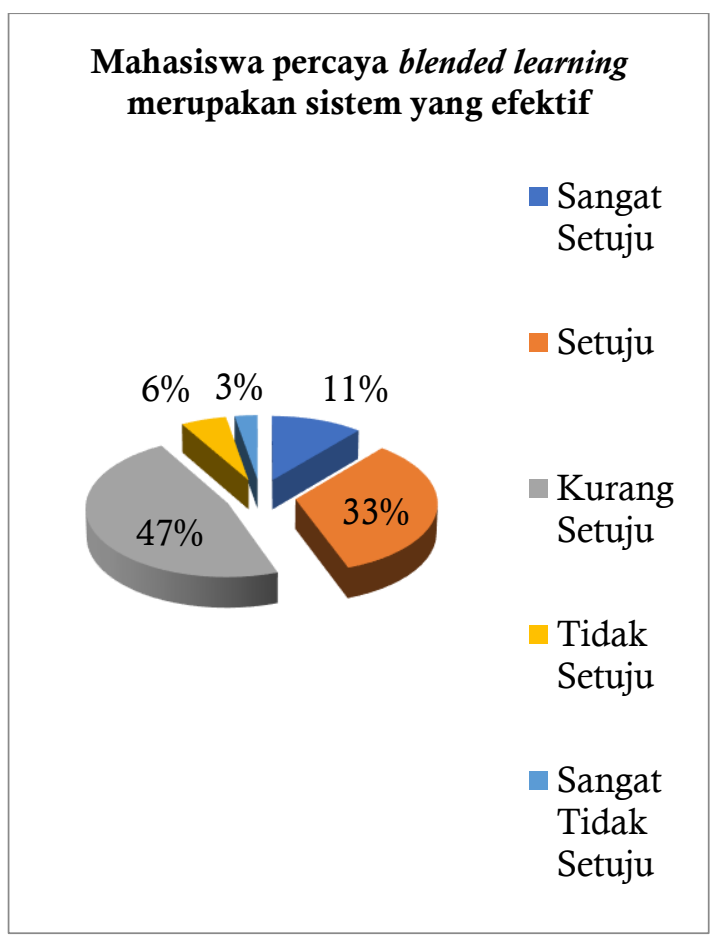

Gambar 7. Mahasiswa percaya blended learning merupakan system yang efektif

Gambar 7 menunjukkan bahwa $44,44 \%$ mahasiswa percaya bahwa blended learning adalah sistem yang efektif. Blended learning adalah kombinasi dari pembelajaran antara pembelajaran tatap muka dan e-learning. Hal ini menjadikan blended learning model pembelajaran yang efektif, karena mahasiswa dapat belajar di mana saja dan kapan saja maka materi juga akan dibahas di kelas. Dengan 
demikian, pembelajaran akan berjalan lebih efektif.Hal ini sesuai dengan temuan Sharma (1997) bahwa persepsi mahasiswa tentang pembelajaran mempengaruhi pendekatan pembelajaran.

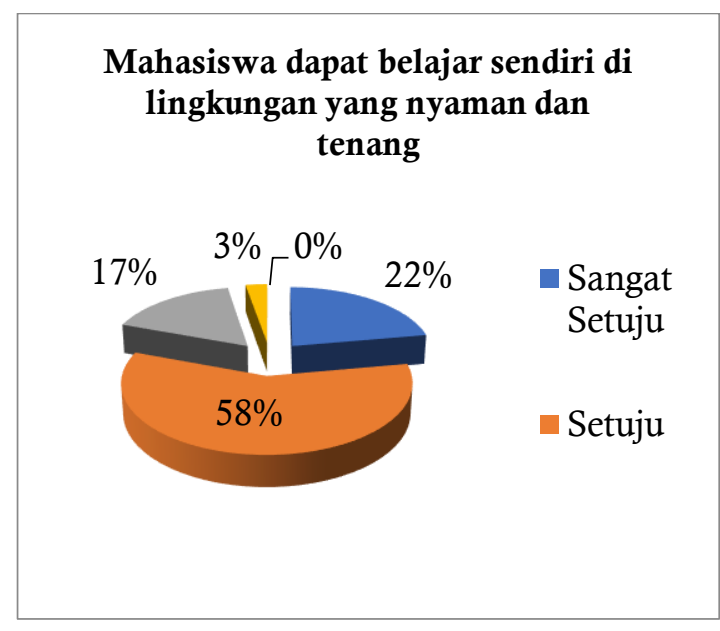

Gambar 8. Mahasiswa dapat belajar sendiri di lingkungan yang nyaman dan tenang

Berdasarkan gambar 8, dapat dilihat bahwa $80.56 \%$ mahasiswa dapat belajar sendiri di lingkungan yang nyaman dan tenang.Blended learning membantu mahasiswa untuk belajar di lingkungan yang lebih nyaman dan tenang. Hal itu karena blended learning memberikan fleksibilitas untuk belajar di mana saja dan kapan saja. Mahasiswa dapat mengatur jadwal belajar mereka dan membuat target pembelajaran. Menurut de George-Walker \& Keeffe (2010) bahwa keberhasilan seorang peserta didik adalah ketika ia peduli akan pembelajarannya dan kebutuhan situasi serta pilihannya dan dapat digunakan untuk memilih format pembelajaran yang menyesuaikan dengan kebutuhannya yang berubah.

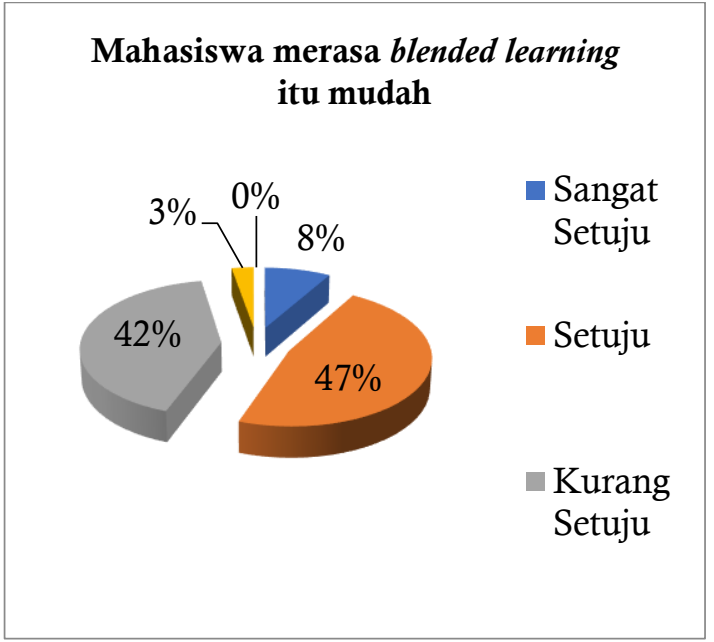

Gambar 9. Mahasiswa merasa blended learning itu mudah

Gambar 9 memberikan informasi bahwa 55,56\% mahasiswa merasa blended learning itu mudah. Pendapat para mahasiswa ini adalah karena mahasiswa merasa bahwa model pembelajaran blended dapat dengan mudah diikuti. Mahasiswa juga dapat belajar secara mandiri maka jika ada sesuatu yang belum dipahami, mereka dapat mendiskusikannya selama pembelajaran tatap muka. Berdasarkan hasil ini, diharapkan dapat membantu mahasiswa belajar dengan sukses.

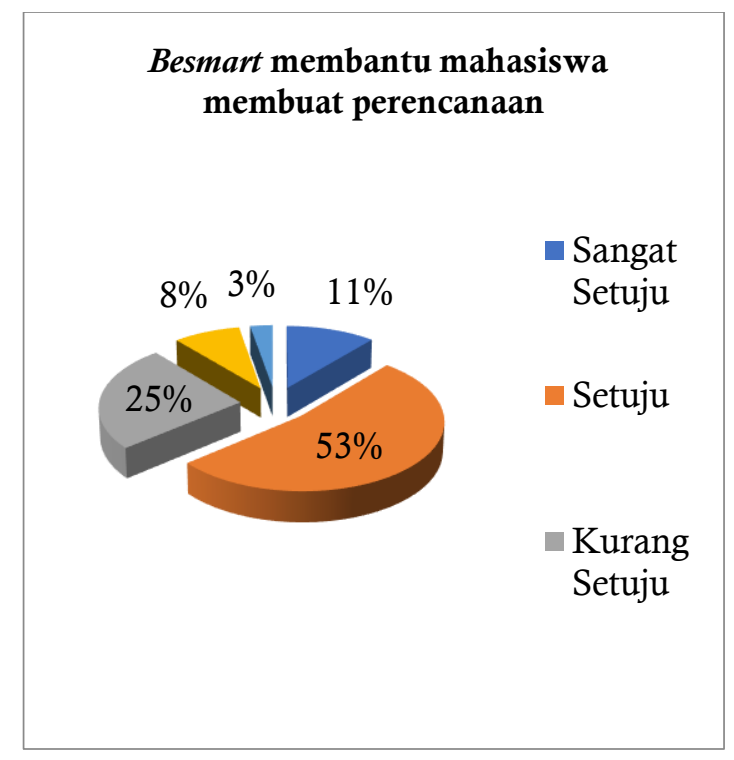

Gambar 10.Besmart membantu mahasiswa membuat perencanaan

Gambar 10 menjelaskan bahwa 63,89\% mahasiswa berpendapat belajar di Besmart membantu mereka membuat rencana. Hal itu 
karena dalam blended learning dapat belajar kapan saja sesuai dengan tenggang waktu, sehingga membantu mahasiswa membuat rencana untuk setiap materi dan tugas yang dikerjakan. Mahasiswa dapat belajar membuat perencanaan yang baik ketika mengerjakan tugas agar tepat waktu.

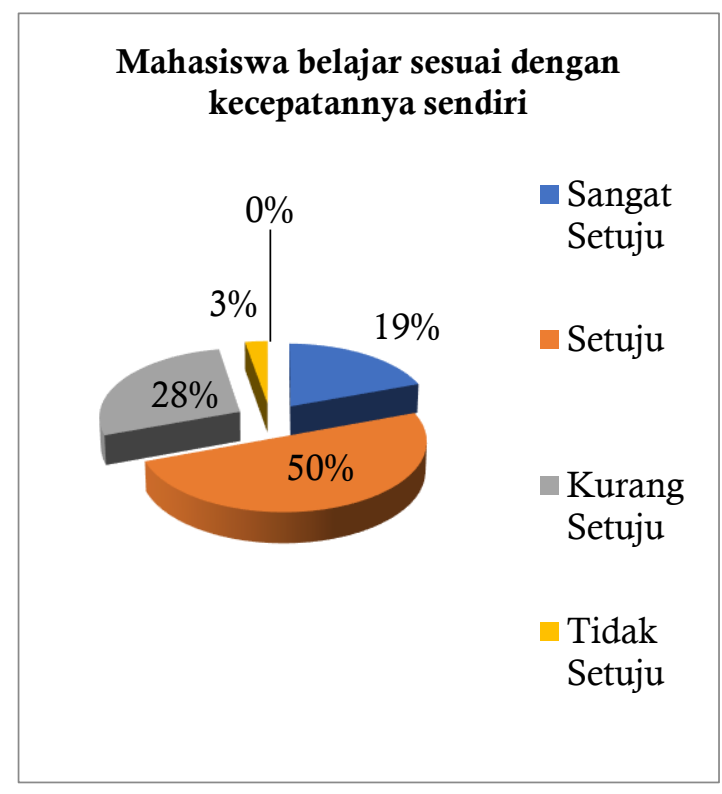

Gambar 11. Mahasiswa belajar sesuai kecepatannya sendiri

Berdasarkan gambar 11, 69.44\% mahasiswa dapat belajar dengan kecepatan mereka sendiri. Implementasi blended learning tentu akan membantu mahasiswa belajar dengan kecepatan mereka sendiri. Hal itu karena dalam blended learning mahasiswa dapat mengakses kapan saja sesuai dengan timeline pembelajaran, sehingga mahasiswa dapat mempelajari materi dan mengerjakan tugas sesuai dengan kecepatan mereka dan kemudian dapat melanjutkan ketika mengakses Besmart.

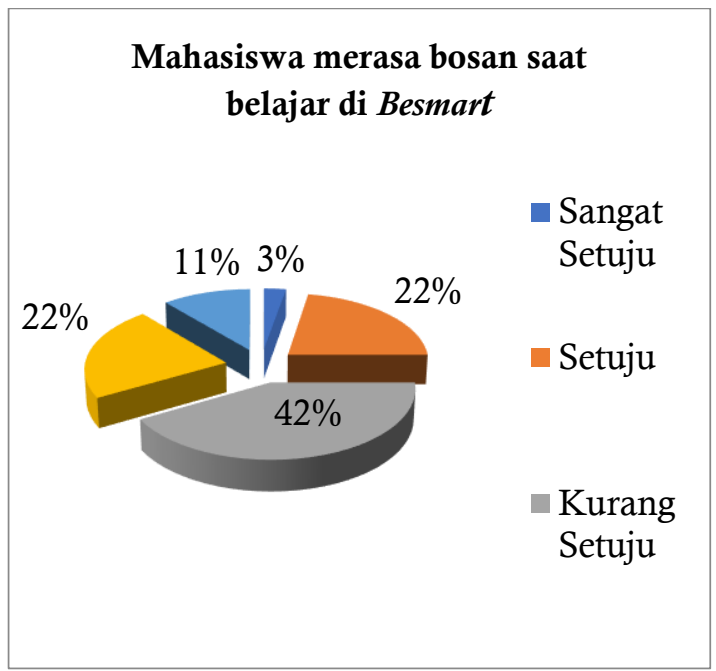

Gambar 12 Mahasiswa merasa bosan saat belajar diBesmart

Gambar 12 memberikan informasi bahwa $25 \%$ mahasiswa merasa bosan saat belajar di Besmart. Hal ini sekitar 1: 4 mahasiswa bosan ketika belajar di Besmart. Hal itu karena konten dari Besmart relatif sama. Konten dari Besmart tidak memiliki inovasi dalam pembelajaran kepada mahasiswa. Selain itu, pembaruan konten juga diperlukan agar mahasiswa merasa termotivasi ketika berpartisipasi dalam blended learning.

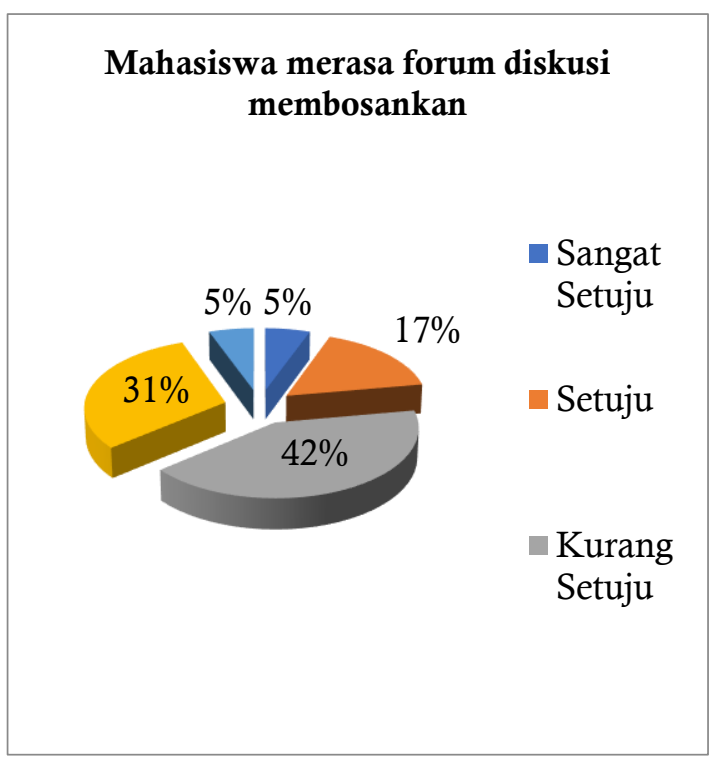

Gambar 13. Mahasiswa merasa forum diskusi membosankan

Berdasarkan gambar 13, dapat dilihat bahwa $22.22 \%$ mahasiswa merasa forum diskusi sangat membosankan. Hal itu karena 
forum diskusi mayoritas berisi pertanyaan diskusi dari dosen dan kemudian mahasiswa saling menjawab dan merespons. Forum diskusi diharapkan lebih bervariasi sehingga siswa merasa perlu dan termotivasi untuk berdiskusi satu sama lain melalui forum di Besmart.

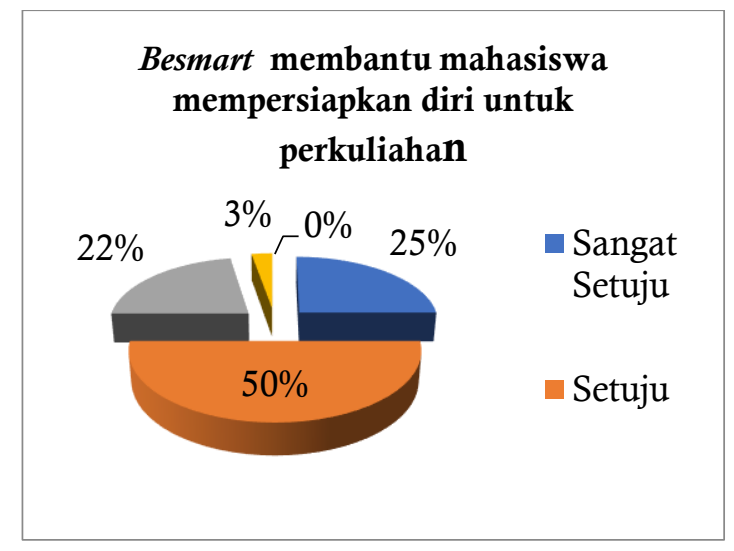

Gambar 14.Besmart membantu mahasiswa mempersiapkan diri untuk perkuliahan

Gambar 14 menjelaskan bahwa $75 \%$ mahasiswa berpendapat Besmart membantu mereka mempersiapkan diri untuk kuliah. Implementasi blended learning yang melibatkan pembelajaran tatap muka dan e-learning membantu mahasiswa mempersiapkan diri untuk kuliah. Mahasiswa sudah mengetahui ruang lingkup materi dan tugas mereka bersama dengan batas waktu pengumpulan. Oleh karena itu, mahasiswa dapat membuat jadwal belajar dan mengerjakan tugas untuk kegiatan kuliah mereka sendiri.

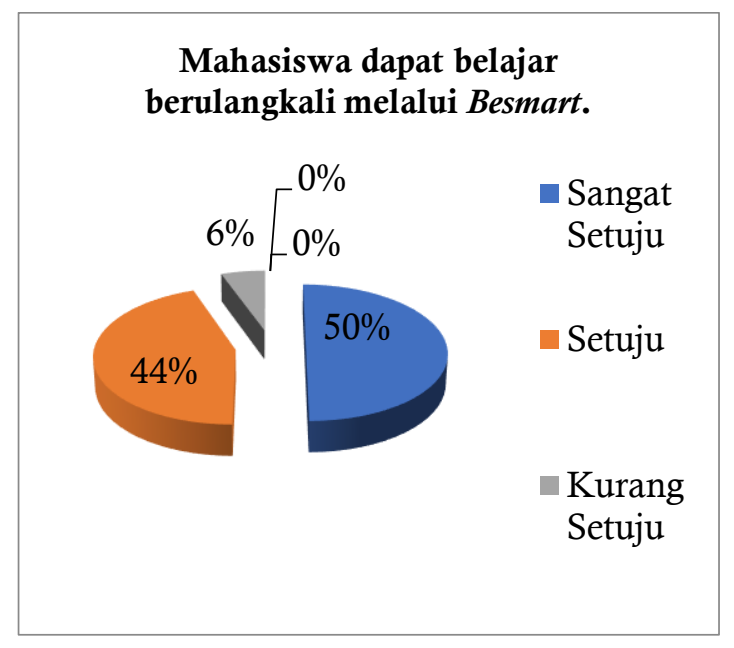

Gambar 15.Mahasiswa dapat belajar berulang kali melalui Besmart.
Gambar 15 memberikan informasi bahwa 94.44\% mahasiswa dapat belajar berulang kali melalui Besmart. Hal itu karena implementasi blended learning dapat diakses di mana saja dan kapan saja, sehingga mahasiswa dapat dengan mudah mengakses Besmart berulang kali sesuai dengan kebutuhan mahasiswa.

\section{SIMPULAN}

Simpulan dalam penelitian ini adalah implementasi blended learning pada mata Kuliah Strategi Pembelajaran Akuntansi adalah blended learning merupakan sistem yang baru, mudah, dan efektif. Melalui Besmart, sebagian besar mahasiswa merasa bertanggung jawab untuk kuliah, termotivasi, membantu membuat rencana, dan mempersiapkan diri sebelum pergi ke kelas untuk kuliah. Mahasiswa dapat belajar di lingkungan yang nyaman, sesuai dengan kecepatan mereka sendiri dan dapat belajar berulang kali. Kemudian, 38,89\% mahasiswa berpikir bahwa Besmart lebih baik daripada metode lain. Sebagian kecil mahasiswa berpendapat bahwa mereka merasa bosan, merasa sulit untuk belajar melalui Besmart, dan forum diskusi yang membosankan.

\section{DAFTAR PUSTAKA}

Aiman, M., Bahrin, K., Othman, F., Hayati, N., Azli, N., \& Talib, F. (2016). Jurnal Teknologi Full Paper INDUSTRY 4.0: A Review On Industrial Automation And Robotic. 78, 2180-3722. Retrieved from www.jurnalteknologi.utm.my

Akkoyunlu, B., \& Yilmaz-Soylu, M. (2008). Development of a scale on learners' views on blended learning and its implementation process. Internet and Higher Education, 11(1), 26-32. https://doi.org/10.1016/j.iheduc.2007.1 2.006

Al-ani, W. T. (2013). Blended Learning Approach Using Moodle and Student's Achievement at Sultan Qaboos University in Oman. Journal of Education and Learning, 2(3). https://doi.org/10.5539/jel.v2n3p96

Bonk, C. J., \& Kim, K. (2004). Future Directions 
Of Blended Learning In Higher Education And Workplace Learning Settings.

Cheung, K. S., Lam, J., Lau, N., \& Shim, C. (2010). Instructional design practices for blended learning. 2010 International Conference on Computational Intelligence and Software Engineering, CiSE 2010, 0-3. https://doi.org/10.1109/CISE.2010.567 6762

de George-Walker, L., \& Keeffe, M. (2010). Self-determined blended learning: A case study of blended learning design. Higher Education Research and Development, 29(1), 1-13.

https://doi.org/10.1080/0729436090327 7380

Hilliard, A. T. (2015). Global Blended Learning Practices For Teaching And Learning, Leadership And. Journal of International Education Research, 11(3), 179-188.

Jackling, B. (2005). Perceptions of the learning context and learning approaches: Implications for quality learning outcomes in accounting. Accounting Education, 14(3), 271-291. https://doi.org/10.1080/0693928050003 6364

Kintu, M. J., Zhu, C., \& Kagambe, E. (2017). Blended learning effectiveness: the relationship between student characteristics, design features and outcomes. International Journal of Educational Technology in Higher Education, 14(1). https://doi.org/10.1186/s41239017-0043-4

$\mathrm{Lu}$, Y. (2017). Industry 4.0: A survey on technologies, applications and open research issues. Journal of Industrial Information Integration, 6, 1-10. https://doi.org/10.1016/j.jii.2017.04.005

Owston, R., York, D., \& Murtha, S. (2013). Student perceptions and achievement in a university blended learning strategic initiative. Internet and Higher Education, 18, 38-46. https://doi.org/10.1016/j.iheduc.2012.1 2.003
Porter, W. W., Graham, C. R., Spring, K. A., \& Welch, K. R. (2014). Blended learning in higher education: Institutional adoption and implementation. Computers and Education, 75, 185-195. https://doi.org/10.1016/j.compedu.2014 .02 .011

Sharma, D. S. (1997). Accounting students' learning conceptions, approaches to learning, and the influence of the learning-teaching context on approaches to learning. International Journal of Phytoremediation, 21(1), 125-146. https://doi.org/10.1080/0963928973315 32

Stockwell, B. R., Stockwell, M. S., Cennamo, M., \& Jiang, E. (2015). Blended Learning Improves Science Education. Cell, 162(5), 933-936. https://doi.org/10.1016/j.cell.2015.08.0 09

Xiao, J. (2012). Tutors' influence on distance language students' learning motivation: voices from learners and tutors. Distance Education, 7919(June). https://doi.org/10.1080/01587919.2012. 72316 